\title{
Effects of Predacious Insects on the Population Dynamics of Three Spider Mite Species (Acari: Tetranychidae) on Japanese Pear ${ }^{\dagger}$
}

\author{
Hidenari KISHIMOTo*, ${ }^{*}$ and Ishizue ADACHI \\ National Institute of Fruit Tree Science, Tsukuba 305-8605, Japan
}

(Received 21 November 2005; Accepted 3 April 2006)

\begin{abstract}
The effects of predacious insects on the population dynamics of three spider mite species, Amphitetranychus viennensis, Tetranychus urticae, and Panonychus citri, which are serious pests infesting the Japanese pear, were compared by experimentally introducing each spider mite species onto Japanese pear trees in an orchard. A. viennensis and T. urticae immediately decreased in density after the introduction, because the density of predacious insects, Scolothrips takahashii and Feltiella sp., increased steeply. In contrast, P. citri increased rapidly, reaching a maximum number of 37.9 adult females per leaf 15 days after introduction, because of the lack of immediate response of the predators, and thereafter decreased abruptly with the occurrence of voracious predacious insects, Oligota spp. and Stethorus japonicus. Another experiment in which the predators were excluded by bagging shoots was also carried out, with the result that the densities of all the spider mite species increased. These results confirmed that predacious insects suppressed the density of spider mites in different fashions: against A. viennensis and T. urticae, even when they were at low densities, the predacious insects responded swiftly, whereas against $P$. citri, predacious insects occurred only when the spider mite density became high.
\end{abstract}

Key words: Population dynamics, Amphitetranychus viennensis, Tetranychus urticae, Panonychus citri, Predacious insects, Japanese pear

\section{INTRODUCTION}

The population dynamics of spider mites are affected by various biotic and abiotic factors. In particular, predators, such as predacious mites and insects, play important roles in suppressing spider mite populations (e.g. Huffaker et al., 1970; van de Vrie, 1985; Takafuji, 1996; Kitashima and Gotoh, 2003). However, little is known regarding the influence of predators on the population dynamics of individual spider mite species in the field. On the Japanese pear, a wide variety of genera and species of spider mites occur and cause serious damage (Ehara and Shinkaji, 1975; Kishimoto, 2002). Thus, for the effective control of these spider mites through integrated pest management programs, the influence of predators on the population dynamics of each species of spider mite needs to be evaluated.

Kishimoto (2002) studied the seasonal occurrence of spider mites and their predators in

\footnotetext{
* Corresponding author: e-mail: kisimoto@affrc.go.jp

Contribution No. 1410 of the National Institute of Fruit Tree Science

* Present address: Research Team for Entomology, Kuchinotsu, National Institute of Fruit Tree Science, Kuchinotsu, Nagasaki 859-2501, Japan
} 
three Japanese pear orchards, focusing on different dominant spider mite species, Amphitetranychus viennensis (Zacher), Tetranychus urticae Koch, or Panonychus citri (McGregor). The peak densities of spider mites differed among these orchards, reflecting the difference of the dominant spider mite species: $P$. citri reached a higher peak density than $\operatorname{did} A$. viennensis or T. urticae, although predacious insects were abundant in all orchards. This suggests that predacious insects would be less effective in suppressing $P$. citri than in suppressing A. viennensis and T. urticae. Nevertheless, because the study was carried out in different orchards, other factors, such as differences in the agrochemical spraying program, may relate to the difference in the population dynamics among spider mite species.

The objective of this study is to demonstrate differences in the effect of predacious insects in suppressing each spider mite species, by experimentally introducing spider mites into a single Japanese pear orchard with relatively homogenous conditions.

\section{MATERIALS AND METHODS}

Experimental orchard. The experimental orchard was located in the National Institute of Fruit Tree Science, Ibaraki Prefecture, eastern Japan. The orchard is about 25 a, and consists of 39 Japanese pear trees of 4 varieties, Chojuro, Nijisseiki, Kosui, and Hosui. Adjoining the pear trees are 17 peach trees, 8 apple trees, and 14 grapevines. No pesticides and acaricides except for petroleum oil in winter are sprayed in this orchard, whereas fungicides are sprayed 11 times a year against black spot, scab, and rust diseases.

Spider mites. In this study, three species of spider mites belonging to different genera, $A$. viennensis, $T$. urticae, and P. citri, were used, because they were found to be the dominant pest species on the Japanese pear in a previous study (Kishimoto, 2002). T. urticae and $P$. citri were collected in August 1997, and A. viennensis in October 1997 from Japanese pear orchards at the National Institute of Fruit Tree Science, and reared for successive generations as stock cultures. A. viennensis were reared on detached pear leaves placed on wet cotton at $23^{\circ} \mathrm{C}$ and $16 \mathrm{~L}: 8 \mathrm{D}$, T. urticae were reared on detached lima bean leaves and P. citri on detached citrus leaves at $23^{\circ} \mathrm{C}$ and $16 \mathrm{~L}: 8 \mathrm{D}$. The latter two species were reared on detached pear leaves about 15 days before the commencement of the experiment.

Evaluation of the effect of predators by experimentally introducing each spider mite species. A large number of individuals of $A$. vienennsis, T. urticae or $P$. citri were introduced onto pear leaves in order to clarify the species composition of predators and their effects on each spider mite species. For the introduction, a small piece $(2 \mathrm{~cm} \times 2 \mathrm{~cm})$ of pear leaf cut from the stock culture of each species was used, on which were generally 30 to 50 adult females, and many eggs and immature individuals.

Three trees were selected in the experimental pear orchard, and then three current shoots were selected from each tree. Each spider mite species was introduced onto a current shoot in each of the three trees on 5 August 1998 by stapling the piece of pear leaf described above to the 1st, 5th, and 10th leaves from the tip of the current shoot. Thus, 3 current shoots per spider mite species were prepared. The initial densities of the field populations of spider mites were extremely low in the orchard when the spider mites were introduced. After an interval of 7 to 8 days, the numbers of spider mites (adult females) and their predators (all 
A. viennensis

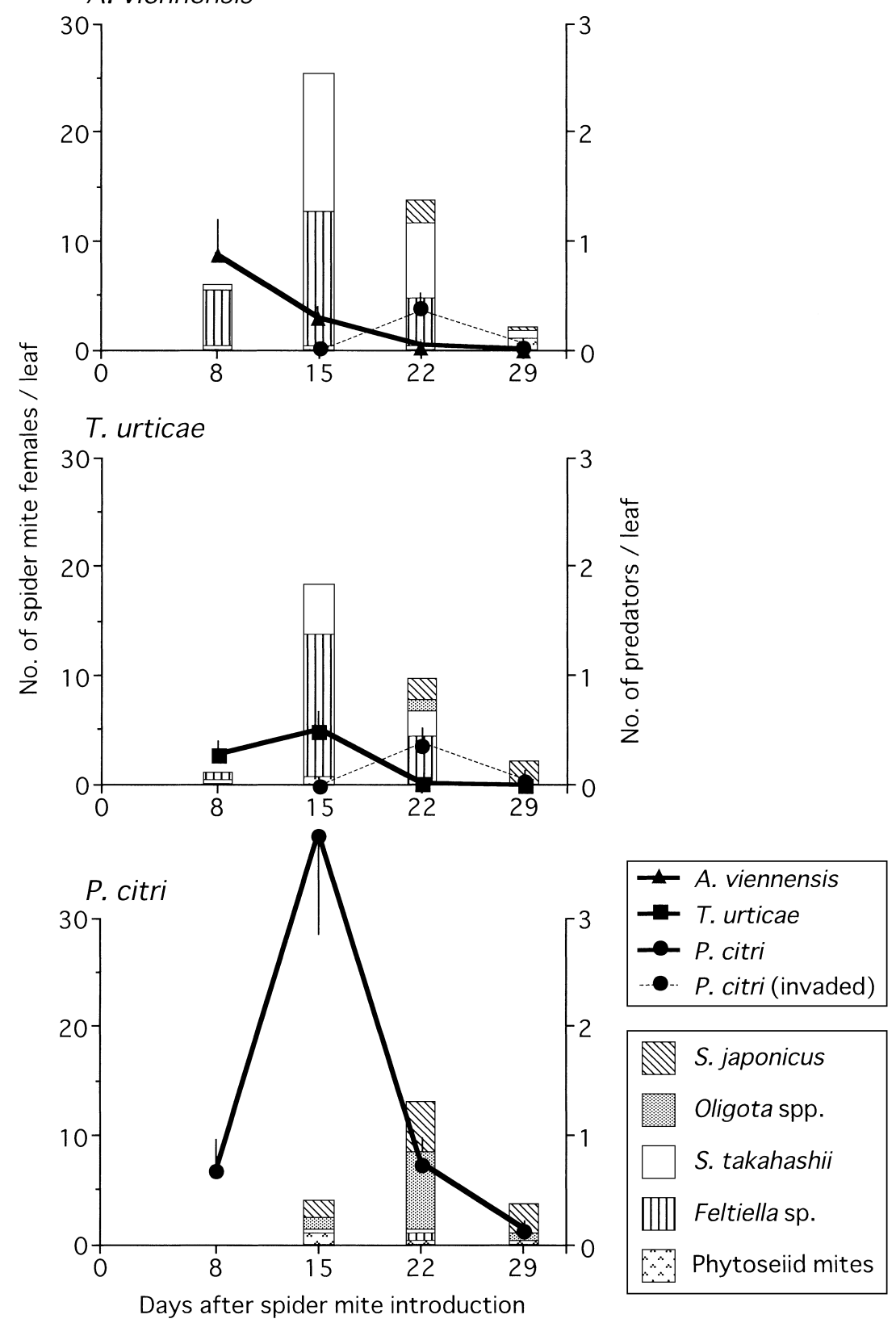

Fig. 1. Changes in the density of spider mites and their predators (all developmental stages observed) on the Japanese pear shoots on which each spider mite species was introduced. The spider mites were introduced on 5 August 1998. Error bars show the standard error. 

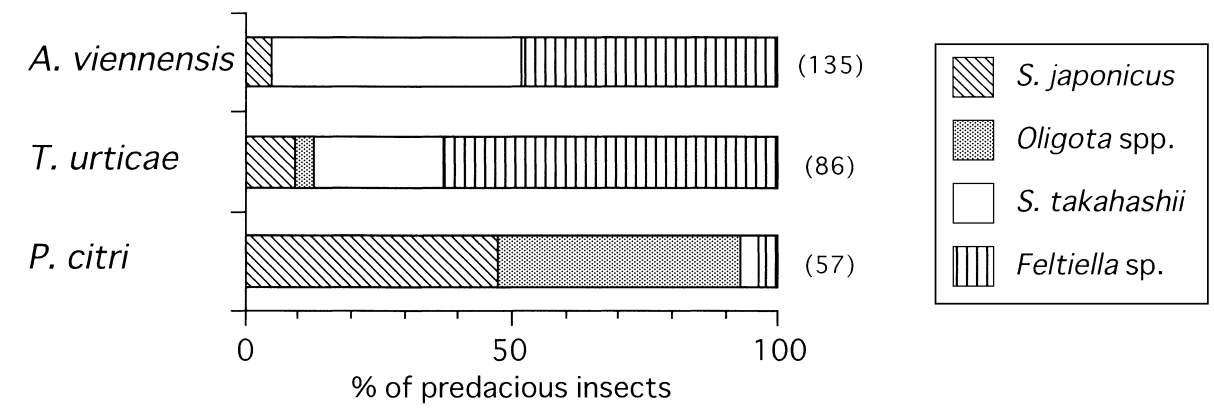

Fig. 2. Percentage of predacious insects (all developmental stages observed) collected during the census period from shoots on which each spider mite species was introduced. Numerals in parentheses represent the number of individuals observed.

developmental stages observed) were counted using a magnifying lens $(\times 10)$ on ten leaves from the tip of the current shoot on which spider mites were introduced.

Evaluation of the effect of predator removal by bagging. To confirm that the numbers of the three spider mite species can increase when no predators exist, predators were excluded by bagging the pear shoots. Six trees were selected in the experimental pear orchard, and three current shoots were then selected from each tree. Each spider mite species was transferred to a current shoot in each of the six trees on 30 July 1999 using the following method: 10 adult females were transferred from the stock cultures to the $1 \mathrm{st}, 5$ th, and 10th leaves from the tip of the current shoot using a fine artist's brush. Thus, 6 current shoots per spider mite species were prepared. Three of these shoots were then enclosed in Tetron gauze bags $(60 \mathrm{~cm}$ in diameter, $100 \mathrm{~cm}$ in length) to prevent predators from attacking the spider mites ('bagged shoot'), and the rest of the shoots were not bagged ('control shoot'). The densities of the field populations of spider mites and their predators were extremely low in the orchard when the spider mites were introduced. Then, after an interval of 7 to 8 days, the numbers of adult female spider mites on ten leaves from the tip of the current shoot where spider mites were transferred were counted, as described above.

\section{RESULTS}

Evaluation of the effect of predators by experimentally introducing each spider mite species.

Figure 1 shows the changes in the densities of each spider mite species and predators on the current shoots on which spider mites were experimentally introduced in 1998. In $A$. viennensis and T. urticae, the mite densities were suppressed immediately after introduction: the maximum densities were only 8.7 and 5.0 adult females per leaf, respectively, and the densities became extremely low 22 days after introduction. The occurrence patterns of predators against both spider mite species were similar (Fig. 1). The predators were observed 8 days after introduction, and increased to peak densities 15 days after introduction. Scolothrips takahashii and Feltiella sp. were abundant (Fig. 2).

On the other hand, in $P$. citri, the mite density increased rapidly, reaching a maximum number of 37.9 adult females per leaf 15 days after introduction (Fig. 1). In addition, the 
A. viennensis

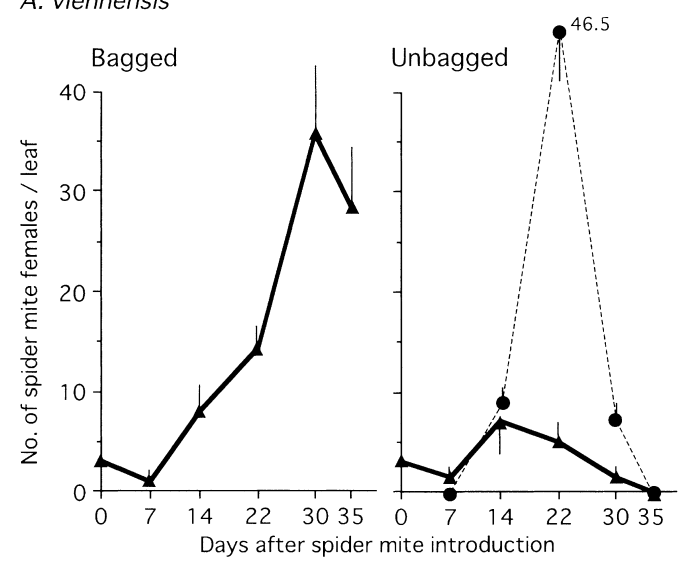

T. urticae

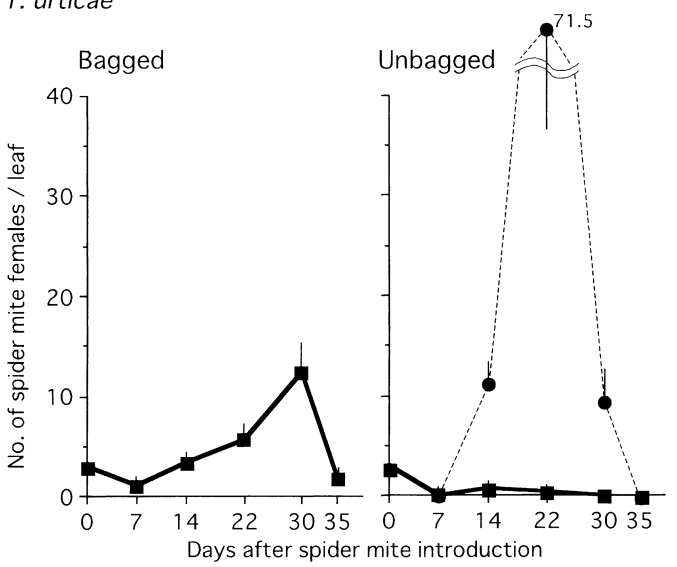

P. citri

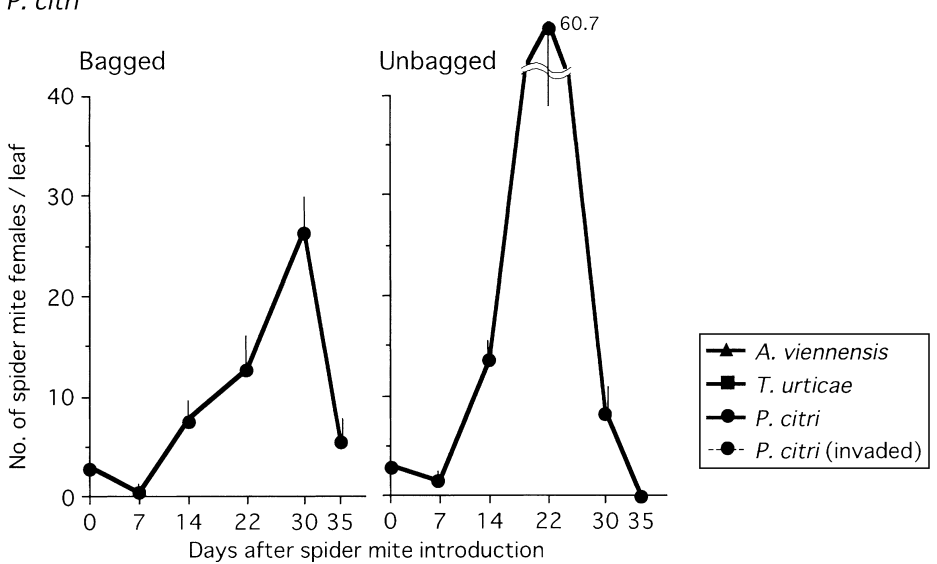

Fig. 3. Changes in the density of spider mites on bagged/unbagged Japanese pear shoots on which each spider mite species was introduced. The spider mites were introduced on 30 July 1999. Error bars show the standard error. 
occurrence of predators was later than that in A. viennensis and T. urticae. No predators were observed 8 days after introduction. The number of predators then increased after the increase of $P$. citri, and peaked 22 days after introduction. The species composition of predators was also different: Stethorus japonicus and Oligota spp. were abundant, whereas Sc. takahashii and Feltiella sp. were rare (Fig. 2). Two Oligota species, O. kashmirica benefica Naomi and O. yasumatsui Kistner, usually occur in this orchard although $O$. yasumatsui are rare (Kishimoto, 2002). In this study, 21 larvae and 5 eggs of Oligota species were observed; all larvae were $O$. kashmirica benefica, although it was impossible to identify the two Oligota species in the egg stage.

In the experimental orchard, the field population of $P$. citri increased in density from mid-August to early September in 1998, and invaded the experimental shoots (Fig. 1). However, in shoots on which A. viennensis or T. urticae were introduced, the timing of shoot invasion was late and the number of invaders was relatively low. Therefore, it was considered that the invaders had only a slight effect on the fluctuation of $P$. citri densities on the experimental shoots where P. citri was introduced, although it was impossible to distinguish introduced mites from invaders.

Evaluation of the effect of predator removal by bagging.

On the bagged shoots, the densities of all spider mite species increased except for 7 days after introduction (Fig. 3). This result shows that these spider mite species can increase in an experimental orchard when predators are excluded. Afterward, the spider mite densities abruptly decreased 35 days after introduction, because predators such as Sc. takahashii and Phytoseiid mites invaded through the mesh of the bags due to bag deterioration. On the other hand, on the unbagged shoots, the density changes in the three spider mite species were similar to those of the mass introduction experiment in 1998 (Fig. 3). However, a large number of $P$. citri invaded the unbagged shoots due to an unexpected outbreak in the experimental orchard (Fig. 3). Therefore, invaders may affect the density changes in these spider mite species. In particular, on the shoots where $P$. citri were introduced, the fluctuation of the number of introduced $P$. citri was unclear, because it was impossible to distinguish introduced mites from invading ones.

\section{DISCUSSION}

The occurrence of predacious insects differed among spider mite species. Against $A$. viennensis and T. urticae, even when they were at low densities, the predacious insects, mainly Sc. takahashii and Feltiella sp., occurred swiftly, whereas, against P. citri, no predacious insects occurred when the spider mite was at a low density. The occurrence of Sc. takahashii and Feltiella sp. was obviously affected by spider mite species. Kishimoto (2002) suggested that each species of predacious insect showed a different response to the density of each spider mite species: St. japonicus and Feltiella sp. seemed to respond to A. viennensis or T. urticae even when their densities were low; Sc. takahashii also seemed to respond to T. urticae even when its density was low, but Oligota spp. seemed to respond to high prey densities rather than to specific prey species. This study confirmed this supposition regarding the response of Feltiella sp. and Sc. takahashii. However, the 
responses of Oligota spp. and St. japonicus against each spider mite species remained unclear in this study. In particular, the response of St. japonicus in this study conflicted with this supposition: St. japonicus was rare on the shoots on which A. viennensis or T. urticae were introduced. St. japonicus is well-known as an extremely voracious predator (Gotoh et al., 2004; Mori et al., 2005). Thus, the numbers of A. viennensis and T. urticae were so small in this experiment that St. japonicus may have not responded to these spider mites.

This study demonstrated differences in the effectiveness of predacious insects against each spider mite species. A. viennensis and T. urticae were suppressed by predacious insects even when the spider mite density was low. On the other hand, in P. citri, predacious insects occurred only when the spider mite density became high, although they played an important role in the abrupt decline in $P$. citri density. Thus, the peak density of $P$. citri was higher than that of $A$. viennensis or $T$. urticae. Although predators are known to play important roles in suppressing spider mite populations, Kishimoto (2002) suggested that predators, in particular predacious insects, are less effective in suppressing $P$. citri than A. viennensis and T. urticae. This study confirmed this inference and partly revealed the mechanism of the difference in the effect of predacious insects against each spider mite species. Additional studies will be needed on factors affecting the response of each predacious insect species to each spider mite species to understand the characteristics of each predacious insect species as natural enemies of spider mites on Japanese pear.

\section{ACKNOWLEDGEMENTS}

I am indebted to Professor A. Takafuji of the Laboratory of Ecological Information, Kyoto University for his critical reading of this manuscript. This study was partly supported by a Grant-in-Aid (Development of Innovative Technologies for Sustainable Agriculture) from the Ministry of Agriculture, Forestry and Fisheries of Japan.

\section{REFERENCES}

Ehara, S. and N. Shinkaji (eds.) (1975) An Introduction to Agricultural Acarology. Zenkoku Nouson Kyouiku Kyoukai, Tokyo. 328 pp. (in Japanese).

Gotoh, T., M. Nozawa and K. Yamaguchi (2004) Prey consumption and functional response of three acarophagous species to eggs of the two-spotted spider mite in the laboratory. Applied Entomology and Zoology, 39: 97-105.

Huffaker, C. B., M. van de Vrie and J. A. McMurtry (1970) Ecology of tetranychid mites and their natural enemies: a review II. Tetranychid populations and their possible control by predators: an evaluation. Hilgardia, 40: 391-458.

Kishimoto, H. (2002) Species composition and seasonal occurrence of spider mites (Acari: Tetranychidae) and their predators in Japanese pear orchards with different agrochemical spraying programs. Applied Entomology and Zoology, 37: 603-615.

Kitashima, Y. and T. Gotoh (2003) Population dynamics of Panonychus osmanthi (Acari: Tetranychidae) on two Osmanthus species. Experimental and Applied Acarolorgy, 29: 227-240.

Mori, K., M. Nozawa, K. Arai and T. Gotoh (2005) Life-history traits of the acarophagous lady beetle, Stethorus japonicus at three constant temperatures. Biocontrol, 50: 35-51.

Takafuji, A. (1996) Population dynamics. In Principles of Plant Acarology (eds., Ehara, S. and N. Shinkaji). Zenkoku Nouson Kyouiku Kyoukai, Tokyo, pp. 124-140 (in Japanese).

van de Vrie, M. (1985) Apple. In Spider Mites: Their Biology, Natural Enemies and Control, Vol. 1B: (eds., Helle, W. and M. W. Sabelis). Elsevier, Amsterdam, pp. 311-325. 


\section{摘要}

ナシを加害するハダニ 3 種の個体群動態に及ぼす捕食性昆虫類の影響

岸本 英成・足立 礎（果樹研）

ナシを加害するハダニ種ごとの密度変動に及ぼす捕食性昆虫類の影響の違いを評価するた めに，同じナシ園内にオウトウハダニ，ナミハダニ，ミカン八ダニを接種した区を設定し， 各種八ダニ及び捕食性昆虫類の密度変動を比較した. オウトウハダニ接種区打よびナミハダ 二接種区では，接種後ただちに八ダニアザミウマや八ダニバエの発生がみられ，八ダニ密度 は上昇しなかった。 これに対し，ミカン八ダニ接種区では天敵類の発生が遅れ，八ダニ密度 はきわめて高いピークに達した後に, ケシハネカクシ類やキアシクロヒメテントウの発生に より急激に低下した，一方，各種八ダニを接種した後，網掛けによって天敵類を排除した区 では，いずれの八ダニ種でも密度が上昇した，以上から，オウトウハダニ，ナミハダニは低 密度時でも天敵類の捕食を受けやすいのに対し, ミカン八ダニは天敵類による密度抑制を受 けにくく高密度に達しやすいことが示唆された. 